\title{
Mild Mitochondrial Uncoupling Decreases Experimental Atherosclerosis, A Proof of Concept
}

\author{
Gabriel G Dorighello ${ }^{1,2}$, Juliana C Rovani ${ }^{1}$, Bruno A Paim², Thiago Rentz ${ }^{1}$, Leandro H P Assis ${ }^{1}$, \\ Anibal E Vercesi ${ }^{2}$ and Helena C F Oliveira ${ }^{1}$ \\ ${ }^{1}$ Department of Structural and Functional Biology, Biology Institute, State University of Campinas, Campinas, SP, Brazil \\ ${ }^{2}$ Department of Clinical Pathology, Faculty of Medical Sciences, State University of Campinas, Campinas, SP, Brazil
}

Aim: Atherosclerosis is responsible for high morbidity and mortality rates around the world. Local arterial oxidative stress is involved in all phases of atherosclerosis development. Mitochondria is a relevant source of the oxidants, particularly under certain risky conditions, such as hypercholesterolemia. The aim of this study was to test whether lowering the production of mitochondrial oxidants by induction of a mild uncoupling can reduce atherosclerosis in hypercholesterolemic LDL receptor knockout mice.

Methods: The mice were chronically treated with very low doses of DNP (2,4-dinitrophenol) and metabolic, inflammatory and redox state markers and atherosclerotic lesion sizes were determined.

Results: The DNP treatment did not change the classical atherosclerotic risk markers, such as plasma lipids, glucose homeostasis, and fat mass, as well as systemic inflammatory markers. However, the DNP treatment diminished the production of mitochondrial oxidants, systemic and tissue oxidative damage markers, peritoneal macrophages and aortic rings oxidants generation. Most importantly, development of spontaneous and dietinduced atherosclerosis (lipid and macrophage content) were significantly decreased in the DNP-treated mice. In vitro, DNP treated peritoneal macrophages showed decreased $\mathrm{H}_{2} \mathrm{O}_{2}$ production, increased anti-inflammatory cytokines gene expression and secretion, increased phagocytic activity, and decreased LDL-cholesterol uptake.

Conclusions: These findings are a proof of concept that activation of mild mitochondrial uncoupling is sufficient to delay the development of atherosclerosis under the conditions of hypercholesterolemia and oxidative stress. These results promote future approaches targeting mitochondria for the prevention or treatment of atherosclerosis.

Key words: Atherosclerosis, Mitochondrial oxidants, LDL receptor knockout mice, 2,4-dinitrophenol

\section{Introduction}

Atherosclerosis causes mortality mainly due to ischemic heart disease and stroke. Atherogenesis involves local oxidative stress, accumulation of oxidized LDL, and formation of macrophage-derived cholesterol-loaded foam cells and evolves as an unresolved inflammatory disease ${ }^{1,2)}$. The majority of the clinical trials of antioxidants did not decrease cardiovascular diseases-related mortality. This failure is attributed to a limited ability of the antioxidant treatment protocols (types, doses, combinations, and duration) to influence key cells, cell compartments and pathways leading to atherosclerosis ${ }^{3,4)}$. Furthermore, the treatment with antioxidants can disturb certain basic aspects of cell functionality since physiological levels of the oxidants are important for signaling proliferation, differentiation, migration, angiogenesis, and other processes ${ }^{5)}$.

Mitochondrial respiration is an important source of intracellular oxidants ${ }^{6}$. Mitochondria present an efficient antioxidant enzyme system and may decrease the generation of the oxidants through an increase in the respiration rate due to mild uncoupling ${ }^{7,8)}$. Mild

Address for correspondence: HCF Oliveira, Depto. Biologia Estrutural e Funcional, Instituto de Biologia, Universidade Estadual de Campinas, Rua Monteiro Lobato, 255 - Campinas - SP - Brasil - CEP 13083-862. E-mail: ho98@unicamp.br

Received: January 9, 2021 Accepted for publication: May 10, 2021

Copyright@2021 Japan Atherosclerosis Society

This article is distributed under the terms of the latest version of CC BY-NC-SA defined by the Creative Commons Attribution License. 
uncoupling may be caused by endogenous (uncoupling protein activity) or exogenous (drugs) mechanisms that induce partial dissipation of the proton gradient across the inner mitochondrial membrane. As a consequence, mitochondrial respiratory rates are increased to reestablish the membrane electrochemical potential. Enhanced respiration rates decrease the production of the oxidants by several pathways: 1 - decreasing $\mathrm{O}_{2}$ tension in the mitochondrial microenvironment; 2-favoring a more oxidized state of the respiratory chain intermediates; 3- maintaining low NADH levels; and 4- inhibiting the reverse flow of the electrons from Complex II to Complex I ${ }^{8)}$. We have previously reported that elevated generation of mitochondrial oxidants is an independent risk factor for atherosclerosis in LDL receptor knockout mice ${ }^{9,10)}$. In addition, Wang et al. ${ }^{11,12)}$ showed that overexpression of a mitochondria-targeted catalase in macrophages reduces atherosclerosis in LDL receptor knockout mice. Robust experimental evidence linking mitochondrial redox dysfunctions and atherosclerosis has been recently reported ${ }^{13,14)}$.

Mitochondria-targeted antioxidants have been used as a promising anti-atherosclerosis strategy. A wide range of antioxidants are targeted to the mitochondria by conjugation with triphenylphosphonium cation (TPP), such as MitoE, MitoSOD, MitoQ and MitoTempo ${ }^{15,16)}$. In mouse models, MitoQ reduces macrophage content and cell proliferation within atherosclerotic plaques and inhibits multiple features of metabolic syndrome ${ }^{17}$. Aged apoE knockout mice treated with MitoTempo have decreased vascular oxidant levels and atherosclerosis ${ }^{18)}$; however, mice with hypercholesterolemia due to overexpression of PCSK9 showed an increase in atherosclerosis when treated with MitoTempo ${ }^{19)}$. Although of high therapeutic potential, targeting mitochondria for cardiovascular disorders still encounters obstacles ${ }^{20)}$.

2,4-Dinitrophenol (DNP), a protonophore with high affinity for the mitochondrial membrane, is a potent mitochondrial uncoupler that was used for the first time as a drug to induce weight loss in the early $1930 \mathrm{~s}^{21)}$; however, the use of DNP was abandoned due to several lethal cases ${ }^{22)}$. More recently, very low and safe doses of DNP have been used in experimental investigations. Wild-type mice treated with a low dose of DNP showed a decrease in oxidant production in the brain, liver and heart, a reduction in the plasma levels of glucose, insulin and triglycerides and an increase in longevity ${ }^{23)}$. Mice acclimated to thermoneutrality treated with DNP exhibited reduced fat mass and hepatic steatosis and improved glucose tolerance ${ }^{24)}$. In addition, DNP treatment protected against motor dysfunction and neuron loss in a mouse model of Parkinson's disease ${ }^{25}$.

\section{Aim}

The objectives of this study were to investigate whether chronic mild mitochondrial uncoupling induced by low doses of DNP may attenuate the development of atherosclerosis in a mouse model of familial hypercholesterolemia.

\section{Methods}

\section{Animals}

LDL receptor knockout $\left(\mathrm{LDLr}^{-/-}\right)$mouse breeders were purchased from Jackson Laboratory (Bar Harbor, ME) and maintained at the State University of Campinas Multidisciplinary Center for Biological Research in Laboratory Animals (CEMIB/Unicamp, Brazil). Animal experiments were approved by the University Committee for Ethics in Animal Experimentation, protocol \#1969-1 (CEUA/ UNICAMP). Male mice had free access to a standard laboratory rodent chow diet (Nuvital CR1, Colombo, Paraná, Brazil) and were housed at $22 \pm 1{ }^{\circ} \mathrm{C}$ on a $12 \mathrm{~h}$ light/dark cycle. 2,4-dinitrophenol (DNP) treatment was performed daily in the drinking water containing $1 \mathrm{mg} / \mathrm{L} \mathrm{DNP}^{23)}$ over 12 weeks starting from the age of 8 weeks. For diet-induced atherosclerosis experiments, five-month-old male and female LDL receptor knockout mice were treated with DNP and fed with an atherogenic diet (western diet: $22 \mathrm{~g} \%$ fat plus 0.21 g\% cholesterol, Pragsoluções, Jaú, SP, Brazil) for 4 weeks.

\section{Indirect Calorimetry}

The Oxylet System (Pamlab e Harvard Apparatus) was used for the indirect calorimetry. The mice were acclimated to the chamber for 24 hours and the metabolism was measured during the next 24 hours in mice with free access to food and water. The software metabolism v2.2.01 was used to calculate total energy expenditure (EE).

\section{Plasma Biochemical Analysis}

Blood samples were collected from either the retroorbital plexus or the tail tip of anesthetized mice. Samples were obtained after $12 \mathrm{~h}$ of fasting. Total cholesterol, triglycerides and non-esterified fatty acids were measured in fresh plasma using standard commercial kits (Roche-Hitachi ${ }^{\circledR}$, Germany and Wako ${ }^{\circledR}$, Germany). Glucose levels were measured using a hand-held glucometer (Accu-Chek Advantage, Roche Diagnostics $^{\circledR}$, Switzerland). The plasma levels

\section{Advance Publication Journal of Atherosclerosis and Thrombosis}


of insulin, leptin and adiponectin (Millipore, USA), tumor necrosis factor- $\alpha$ (TNF-a) (eBioscience, USA) and C-reactive protein (IBL America, USA) were measured with commercial ELISA kits. Plasma lipoproteins were determined by fast protein liquid chromatography (FPLC) (Amersham-Pharmacia Biotech, Uppsala, Sweden) as described previously ${ }^{26)}$.

\section{Plasma Thiobarbituric Acid Reactive Substances} (TBARS)

Plasma $(100 \mu \mathrm{L})$ was incubated with $200 \mu \mathrm{L}$ of $0.7 \%$ thiobarbituric acid in $0.05 \mathrm{M} \mathrm{NaOH}$ and $60 \mu \mathrm{L}$ of $50 \%$ trichloroacetic acid. Samples were incubated in boiling water for $30 \mathrm{~min}$ followed by centrifugation at $664 \times$ $\mathrm{g}$ for $15 \mathrm{~min}$. A standard curve was prepared using several dilutions of $0.05 \mathrm{mM} \mathrm{1,1,3,3-tetramethoxypropane.}$ The optical density of the samples and standard curve was measured in a microplate reader at $532 \mathrm{~nm}$ (SpectraMax M3, Molecular Devices, USA).

\section{Body Composition and Liver Lipid Content}

The mice and food intake were weighed once per week. The epididymal adipose tissue and liver mass were determined gravimetrically. Mouse carcass composition was determined as described previously in detail by Salerno et al. ${ }^{27)}$. Liver lipids were extracted using the Folch method ${ }^{28)}$. The liver contents of cholesterol and triglycerides were determined using colorimetric enzymatic assays (Roche-Hitachi ${ }^{\circledR}$, Germany) after dissolving the lipid extracts in a Triton-containing buffer.

\section{Liver Protein Carbonyl Content}

The liver protein carbonyl content was estimated according to Reznick and Packer ${ }^{29)}$, as modified by Schild et al. ${ }^{30)}$. Briefly, samples of the liver homogenate were incubated with $10 \mathrm{mM}$ dinitrophenylhydrazine in $2.5 \mathrm{M} \mathrm{HCl}$ for $1 \mathrm{~h}$ at room temperature. The reaction was stopped by the addition of $20 \%$ trichloroacetic acid. The pellets were washed twice with ethanol/ethyl acetate (1/1) and once with $10 \%$ trichloroacetic acid. The protein pellets were dissolved in $6 \mathrm{M}$ guanidine hydrochloride, and the absorption at $370 \mathrm{~nm}$ was determined. Carbonyl content was calculated using the molar absorption coefficient of aliphatic hydrazones $\left(0.022 \mu \mathrm{M}^{-1} \mathrm{~cm}^{-1}\right)$.

\section{Isolation of Mouse Liver Mitochondria}

Mitochondria were isolated by conventional differential centrifugation at $4{ }^{\circ} \mathrm{C}$ as described previously ${ }^{31)}$. The livers were homogenized in 250 $\mathrm{mM}$ sucrose, $1 \mathrm{mM}$ EGTA, and $10 \mathrm{mM}$ HEPES buffer ( $\mathrm{pH}$ 7.2). The mitochondrial suspension was washed twice in the same medium containing $0.1 \mathrm{mM}$
EGTA, and the final pellet was resuspended in 250 $\mathrm{mM}$ sucrose to a final protein concentration of $80-100 \mathrm{mg} / \mathrm{ml}$. The protein concentration was determined by a modified biuret assay. The experiments were done in a standard medium containing $125 \mathrm{mM}$ sucrose, $65 \mathrm{mM} \mathrm{KCl,} 2 \mathrm{mM}$ inorganic phosphate, $1 \mathrm{mM}$ magnesium chloride, and 10 mM HEPES buffer, $\mathrm{pH}$ 7.2, as described previously ${ }^{32)}$.

\section{Isolation of Peritoneal Macrophages}

Anesthetized mice were euthanized, and the epidermal abdominal layer was carefully cut, preserving the peritoneum. Afterward, $6 \mathrm{~mL}$ of icecold PBS (phosphate-buffered saline) was injected into the peritoneum, and approximately $5 \mathrm{~mL}$ of cellcontaining buffer was aspirated from the peritoneum. The cell-containing buffer was then centrifuged for 5 min at $400 \times \mathrm{g}$ at $4{ }^{\circ} \mathrm{C}$. The cell pellet was gently resuspended in RPMI 1640 medium (Vitrocell, Brazil) supplemented with $10 \%$ fetal bovine serum. Cell counting was performed using an automatic cell analyzer (Muse ${ }^{\circledR}$ Millipore Corporation, Hayward, CA, USA.). The peritoneal cells were diluted to $1 \mathrm{x}$ $10^{7}$ cells $/ \mathrm{mL}$, seeded in 96-well $(100 \mu \mathrm{L})$ plates and washed after $2 \mathrm{~h}$ to remove non-adherent cells. Macrophages were ready for experimentation after overnight incubation at $37^{\circ} \mathrm{C}$ and $5 \%(\mathrm{v} / \mathrm{v}) \mathrm{CO}_{2}$.

\section{Global Oxidant Production}

Global oxidant production was monitored using a membrane-permeable fluorescent dye, $2^{\prime}, 7^{\prime}$-dichlor odihydrofluorescein diacetate $\left(\mathrm{H}_{2} \mathrm{DCF}-\mathrm{DA}\right)$. The global oxidant production by isolated mitochondria was monitored as described previously ${ }^{9)}$. In the case of the aorta, two $3 \mathrm{~mm}$ rings from the descending aorta were placed in a well of a 96-well plate in $10 \mu \mathrm{M}$ $\mathrm{H}_{2}$ DCF-DA in PBS buffer containing $11.1 \mathrm{mM}$ glucose, $\mathrm{pH} 7.4$, for $1 \mathrm{~h}$. Then, the fluorescence signal was measured at the excitation/emission wavelengths of 492/517 nm in a SpectraMax M3 microplate reader (Molecular Devices, USA).

\section{$\mathrm{H}_{2} \mathrm{O}_{2}$ Release}

$\mathrm{H}_{2} \mathrm{O}_{2}$ release was quantified using Amplex ${ }^{\circledR}$ red (Molecular Probes, USA) in the presence of horseradish peroxidase (HRP). Isolated-mitochondria: The $\mathrm{H}_{2} \mathrm{O}_{2}$ release in isolated mitochondria was determined as described previously ${ }^{33)}$. Aorta: Two 3 $\mathrm{mm}$ rings of the descending aorta were placed in a well of a 96-well plate with Amplex ${ }^{\circledR}$ red $(10 \mu \mathrm{M})$ and $\operatorname{HRP}(0.2 \mathrm{U} / \mathrm{mL})$ in PBS buffer containing $11.1 \mathrm{mM}$ glucose, $\mathrm{pH} 7.4$, for $1 \mathrm{~h}$. Then, the aortic rings were removed, and the fluorescence signal was measured in 
the buffer at the excitation/emission wavelengths of 530/590 nm (SpectraMax M3, Molecular Devices, USA ${ }^{34)}$. Peritoneal macrophages: Experiments were done in a 96-well plate in $100 \mu$ of PBS buffer containing $11.1 \mathrm{mM}$ glucose, $\mathrm{pH} 7.4$, in the presence of Amplex ${ }^{\circledR}$ red $(25 \mu \mathrm{M})$ and HRP $(0.2 \mathrm{U} / \mathrm{mL})$ in the dark at $37^{\circ} \mathrm{C}$ for $40 \mathrm{~min}$; fluorescence (excitation: 530 $\mathrm{nm}$, emission: $590 \mathrm{~nm}$ ) was measured every $10 \mathrm{~min}$ (SpectraMax M3- Molecular Devices, USA). Catalase $(500 \mathrm{U} / \mathrm{mL})$ was added at least in one well per group as a background control to account for nonspecific signal. Phorbol 12-myristate 13-acetate (PMA) (100 $\mathrm{nM}$ ) was used to activate the macrophages during the assay.

\section{Superoxide Generation}

Total intracellular and mitochondrial superoxide anion generation were determined using the dihydroethidium (DHE) and Mitosox ${ }^{\circledR}$ reagents, respectively (Thermo Fisher Scientific, USA), which are fluorogenic dyes that react with the superoxide anion to produce red fluorescence. The macrophages were incubated with DHE $(10 \mu \mathrm{M})$ or Mitosox $^{\circledR}$ (2 $\mu \mathrm{M})$ in PBS buffer containing $11.1 \mathrm{mM}$ glucose, $\mathrm{pH}$ 7.4 , in the dark at $37^{\circ} \mathrm{C}$ for $30 \mathrm{~min}$. Then, macrophages were washed twice with PBS, and total fluorescence was quantified in a fluorimeter (SpectraMax M3-Molecular Devices) with excitation/ emission wavelengths as follows: DHE: 518/605 nm and Mitosox: 510/580 nm. Fluorescence was corrected against the background fluorescence of the cells without the probes. In the Mitosox plate, the cells were incubated with Hoechst $33342(5 \mu \mathrm{g} / \mathrm{mL})$ (Thermo Fisher Scientific, H3570) in PBS for $15 \mathrm{~min}$ and then fixed with paraformaldehyde $3.7 \%(\mathrm{v} / \mathrm{v})$ in PBS for $10 \mathrm{~min}$ at room temperature. Images of the macrophages were captured by an ImageXpress Micro confocal high content imaging system (Molecular Devices) using Texas Red and DAPI fluorescence filters to obtain a representative image of mitochondrial superoxide generation.

\section{Histological Analysis of Atherosclerosis Lesions}

In situ-perfused hearts were excised, embedded in Tissue-Tek ${ }^{\circledR}$ OCT compound (Sakura, USA), frozen at $-80^{\circ} \mathrm{C}$, cut in $10 \mu \mathrm{m}$-sections along $480 \mu \mathrm{m}$ aorta length from the aortic valve leaflets and stained with Oil Red $\mathrm{O}$ as described previously ${ }^{9}$. A sub-group of slides were immune-stained for CD68, a general marker of macrophages. These sections were blocked with $10 \%$ bovine serum albumin (BSA) and then incubated for $3 \mathrm{~h}$ at room temperature with the primary antibody rat anti-CD68 (1:250; AbD Serotec). The sections were washed and incubated with fluorescent Alexa Fluor-conjugated secondary antibody (Invitrogen). Nuclei were counterstained for 10 min with DAPI. The sections were mounted with VECTASHIELD medium, and pictures were taken with a Leica DMI600B microscope. The lipid and immune-stained lesions areas were quantified using ImageJ (1.45 h) software.

\section{Macrophage In Vitro DNP Dose-Effect and Cell Viability}

$1 \times 10^{5}$ cells were incubated in RPMI 1640 medium supplemented with $10 \%$ fetal bovine serum during $24 \mathrm{~h}$ at $37^{\circ} \mathrm{C}$, in the absence and presence of $50,100,200,400 \mu \mathrm{M}$ DNP. $\mathrm{H}_{2} \mathrm{O}_{2}$ medium concentrations were determined with Amplex red as described above. Cell viability was determined with crystal violet staining, which is a cation-based dye that stain DNA in attached alive cells (dying cells detached from the plate), at the end of incubation. After media removal, cells were fixed with $100 \mu \mathrm{L}$ of paraformaldehyde $4 \%$ during $5 \mathrm{~min}$ and incubated with $100 \mu \mathrm{L}$ crystal violet $0.05 \%$ during $10 \mathrm{~min}$ at room temperature. The stained cells were then washed thoroughly with distilled water, dried and eluted with $100 \mu \mathrm{L}$ of acetic acid (10\%). The absorbance was measure at $590 \mathrm{~nm}$ in a plate reader (Spectramax M3-Molecular Devices, USA).

Gene Expression by Real-Time Quantitative Polymerase Chain Reaction (RT-qPCR)

Peritoneal macrophages were seeded at $3 \times 10^{5}$ cells/well in a 24-wells plate (Nest Biotechnology, 702001, Wuxi, China) in RPMI 1640 medium supplemented with $10 \%$ fetal bovine serum during $24 \mathrm{~h}$ at $37^{\circ} \mathrm{C}$, in the presence and absence of $100 \mu \mathrm{M}$ DNP. Total RNA was extracted using TRIzolTM reagent (ThermoFisher Scientific, 15596026, Rockford, IL) according to the manufacturer's protocol and then quantified in NanoDropTM 2000/2000c spectrophotometer (ThermoFisher Scientific). The amount of $1 \mu \mathrm{g}$ of total RNA was reverse transcribed using a high-capacity cDNA reverse transcription kit (Applied Biosystem, 4368814 , Foster City, CA). The amplification step was carried out using Fast SYBRTM Green Master mix (ThermoFisher Scientific, 4385612), 100 ng of each cDNA, and $200 \mathrm{nM}$ of each forward and reverse oligonucleotide as described below. The oligonucleotides were designed and tested against the Mus musculus genome deposited in the Gene Bank of the National Center for Biotechnology Information (NCBI). RT-qPCR assays were carried out in the StepOne real-time PCR system (Applied Biosystems). The mRNA relative abundance was quantified using 
the threshold cycle method $2\left(-\Delta \Delta \mathrm{C}_{\mathrm{T}}\right)^{35)}$ and the data were normalized against the endogenous controls (ATCB or 36B4). Oligonucleotides used to monitor gene expression by RT-qPCR are described below.

\begin{tabular}{|l|l|l|c|}
\hline Genes & Forward $\left({ }^{\prime} \rightarrow 3^{\prime}\right)$ & Reverse $\left(5^{\prime} \rightarrow 3^{\prime}\right)$ & $\begin{array}{c}\text { Amplicon } \\
\text { size }(\mathrm{bp})\end{array}$ \\
\hline IL-1 $\beta$ & CCTTCCAGGATGAGGACATGA & TGAGTCACAGAGGATGGGCTC & 71 \\
\hline IL-6 & CACGGCCTTCCCTACTTCAC & GGTCTGTTGGGAGTGGTATC & 66 \\
\hline TNF $\alpha$ & CCCTCCTGGCCAACGGCATG & TCGGGGCAGCCTTGTCCCTT & 109 \\
\hline IL-4 & CCAAACGTCCTCACAGCAAC & AAGCCCGAAAGAGTCTCTGC & 157 \\
\hline IL-10 & GCTCTTACTGACTGGCATGAG & CGCAGCTCTAGGAGCATGTG & 105 \\
\hline ARG1 & CTCCAAGCCAAAGTCCTTAGAG & AGGAGCTGTCATTAGGGACATC & 185 \\
\hline 36B4 & GAGGAATCAGATGAGGATATGGGA & AAGCAGGCTGACTTGGTTGC & 72 \\
\hline ACTB & AGAAGCTGTGCTATGTTGCTCTA & TCAGGCAGCTCATAGCTCTTC & 91 \\
\hline
\end{tabular}

\section{IL-10 Secretion by ELISA}

Peritoneal macrophages were seeded at $1 \times 10^{6}$ cells/well in a 24-well plate (Nest Biotechnology, 702001, Wuxi, China) in RPMI 1640 medium supplemented with $10 \%$ fetal bovine serum during $24 \mathrm{~h}$ at $37^{\circ} \mathrm{C}$, in the presence and absence of $100 \mu \mathrm{M}$ DNP. Cytokine content was quantified in the medium using Mouse IL-10 Quantikine ELISA kit (R\&D Systems, M1000B, Minneapolis, MN) according to the manufacturer's protocol. For normalization, adhered cells were harvested and incubated with 100 $\mu L$ RIPA buffer (Sigma-Aldrich, R0278, St. Louis, MO) containing cOmpleteTM Protease Inhibitor Cocktail (Roche, 11697498001 , Mannhein, Germany) during $15 \mathrm{~min}$ at $4{ }^{\circ} \mathrm{C}$. The lysate was centrifuged at $13,000 \mathrm{rpm}, 4^{\circ} \mathrm{C}$ for $15 \mathrm{~min}$. The protein content was determined in the supernatant using PierceTM $660 \mathrm{~nm}$ Protein Assay Reagent (ThermoFisher Scientific, 22660, Rockford, IL) and PierceTM Bovine Serum Albumin Standard prediluted (ThermoFisher Scientific, 23208, Rockford, IL). Absorbance was measured in SpectraMax M3 spectrophotometer (Molecular Devices) at the wavelength of $660 \mathrm{~nm}$.

\section{Macrophage Phagocytosis Assay}

The control and DNP treated peritoneal macrophages $\left(1 \times 10^{5}\right)$ were incubated for $30 \mathrm{~min}$ with $100 \mu \mathrm{L}$ of neutral-red stained zymosan $\left(1 \times 10^{7}\right.$ particles $/ \mathrm{mL})$ and fixed with Baker's solution ( $4 \%$ formaldehyde, $2 \%$ sodium chloride, $1 \%$ calcium acetate) for additional $30 \mathrm{~min}$ at $37^{\circ} \mathrm{C}$. Cells were then washed twice with PBS buffer and the neutral-red stain was solubilized with $0.1 \mathrm{~mL}$ of acidified alcohol (10\% acetic acid, $40 \%$ ethanol in distilled water) for $30 \mathrm{~min}$. The absorbance was then read at $550 \mathrm{~nm}$ as previously described ${ }^{36}$.

\section{Macrophage Cholesterol Uptake Assay}

The peritoneal macrophages $\left(5 \times 10^{5}\right)$ were incubated with $50 \mu \mathrm{g} / \mathrm{mL}$ of oxidized LDL (CuSO $4-$ induced oxidation, $40 \mu \mathrm{M}, 37^{\circ} \mathrm{C}, 24 \mathrm{~h}$ ) in RPMI 1640 medium supplemented with $1 \%$ fetal bovine serum during $24 \mathrm{~h}$ at $37^{\circ} \mathrm{C}$, in the presence and absence of $100 \mu \mathrm{M}$ DNP. The cells were washed twice with PBS buffer and lysed with RIPA buffer. Then, in a black 96 well plate, $10 \mu \mathrm{L}$ of each sample and $40 \mu \mathrm{L}$ of catalase $(20 \mathrm{U} / \mathrm{mL})$ were mixed and incubated for $15 \mathrm{~min}$ at $37^{\circ} \mathrm{C}$ in order to eliminate any peroxides present in reagents or samples ${ }^{37)}$. Next, $100 \mu \mathrm{L}$ of cholesterol oxidase/amplex-red reagent $(0.1 \mathrm{M}$ potassium phosphate buffer, pH 7.4, $50 \mathrm{mM} \mathrm{NaCl}, 5 \mathrm{mM}$ cholic acid, $0.1 \%$ Triton $\mathrm{X}-100,2 \mathrm{U} / \mathrm{ml}$ cholesterol oxidase, $0.2 \mathrm{U} / \mathrm{mL}$ cholesterol esterase, $2 \mathrm{U} / \mathrm{ml} \mathrm{HRP}$, and 100 $\mu \mathrm{M}$ amplex-red) was added, mixed and incubated at $37^{\circ} \mathrm{C}$ for an additional $30 \mathrm{~min}$. Fluorescence was then read at excitation wavelength of $530 \mathrm{~nm}$ and emission wavelength of $590 \mathrm{~nm}$. The cholesterol mass was normalized by total lysate protein using the bicinchoninic acid (BCA) assay kit (ThermoFisher Scientific, USA).

\section{Data Analysis}

The results are presented as the mean \pm SE. Comparisons between the groups were performed by unpaired Student's $t$ test. The level of significance was set at $p \leq 0.05$.

\section{Results}

LDL receptor knockout $\left(\mathrm{LDLr}^{-1-}\right)$ mice were treated for 3 months with low doses of the mitochondrial uncoupler 2,4-dinitrophenol (DNP) in the drinking water, and atherosclerotic risk factors and the size of atherosclerotic lesions at the aortic root were analyzed. The DNP doses were low and slightly modified the whole body metabolic rates, increasing $11 \%$ the $\mathrm{O}_{2}$ consumption rate $(p<0.05)$ in the DNPtreated mice (Fig. 1). The DNP treatment did not change body weight, visceral adipose tissue mass, lean carcass mass, and liver lipid content (Table 1). DNP treatment did not change the plasma levels of total and lipoprotein-associated cholesterol, triglycerides, adipokines (leptin and adiponectin), glucose, insulin, or systemic inflammatory markers (TNF $\alpha$ and C-reactive protein) (Table 2). However, the plasma levels of non-esterified fatty acids were significantly reduced (22\%) in the DNP-treated mice (Table 2). This reduction may represent an energy substrate preference since DNP activates AMPK in the muscles $^{38)}$, thus stimulating $\beta$-oxidation ${ }^{39)}$. Glucose and insulin tolerance were also not modified by DNP 
A
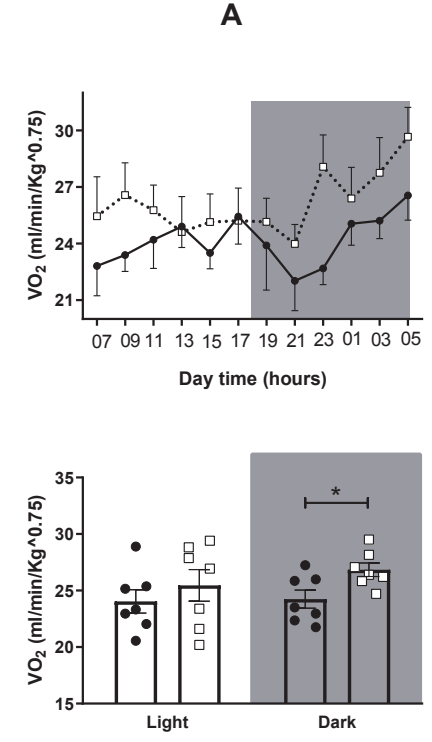

B

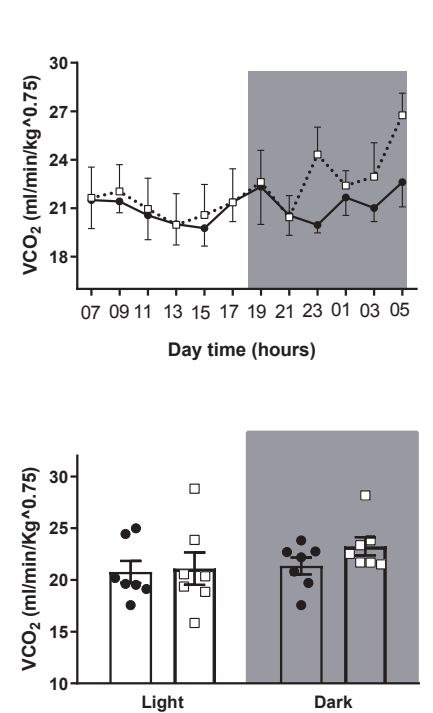

C

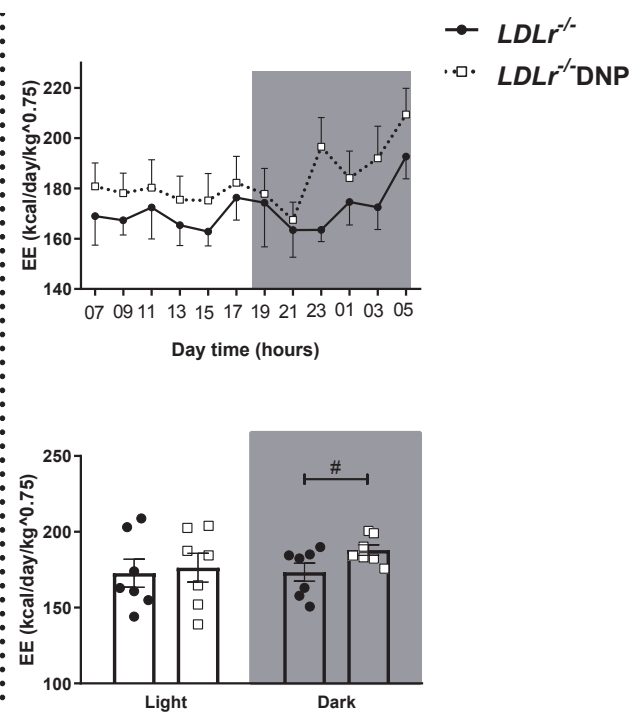

Fig. 1. Indirect calorimetry during 24 hours (light and dark times) in LDL receptor knockout mice (LDLR0) and treated with low doses of 2,4-dinitrophenol (LDLR0-DNP)

Body $\mathrm{O} 2$ consumption (A), $\mathrm{CO} 2$ production (B) and energy expenditure (C) measurement each 2 hours during all day and an average during the light and dark time $\left(n=7,{ }^{*} p=0.023,{ }^{*} p=0.056\right)$.

Table 1. Body weight and composition of LDL receptor knockout mice $\left(L D L r^{-1-}\right)$ treated with or without 2,4-dinitrophenol (DNP) and fed a chow diet

\begin{tabular}{|c|c|c|c|c|c|}
\hline & $L D L r^{-1-}$ & $n$ & $L D L r^{-1-} \mathrm{DNP}$ & $n$ & $P^{*}$ \\
\hline Perigonadal adipose tissue (\% body weight) & $1.00 \pm 0.07$ & 17 & $0.95 \pm 0.08$ & 14 & 0.68 \\
\hline Liver cholesterol (mg/g) & $1.99 \pm 0.11$ & 13 & $2.02 \pm 0.10$ & 11 & 0.86 \\
\hline Liver triglycerides $(\mathrm{mg} / \mathrm{g})$ & $22.5 \pm 2.2$ & 13 & $19.2 \pm 2.3$ & 10 & 0.32 \\
\hline
\end{tabular}

Data are the mean \pm SE $(n) .{ }^{*} P$ values according to the Student's $t$ test.

Table 2. Plasma levels of lipids, glucose, insulin, adipokines and inflammatory proteins in LDL receptor knockout mice $\left(L D L r^{-/-}\right)$ treated with or without 2,4-dinitrophenol (DNP) and fed a chow diet

\begin{tabular}{|c|c|c|c|c|c|}
\hline & $L D L r^{-1-}$ & $n$ & $L D L r^{-1-} \mathrm{DNP}$ & $n$ & $P^{*}$ \\
\hline VLDL-chol (mg/dL) & $13.1 \pm 1.5$ & 8 & $14.2 \pm 2.1$ & 7 & 0.62 \\
\hline HDL-chol (mg/dL) & $101.3 \pm 2.1$ & 8 & $97.3 \pm 2.5$ & 7 & 0.23 \\
\hline Triglycerides (mg/dL) & $120.0 \pm 9.1$ & 16 & $116 \pm 8.5$ & 13 & 0.75 \\
\hline Insulin $(\mathrm{ng} / \mathrm{mL})$ & $1.12 \pm 0.14$ & 7 & $1.31 \pm 0.21$ & 6 & 0.47 \\
\hline Adiponectin $(\mu \mathrm{g} / \mathrm{mL})$ & $7.7 \pm 0.3$ & 7 & $8.2 \pm 0.4$ & 11 & 0.45 \\
\hline Leptin $(\mathrm{ng} / \mathrm{mL})$ & $0.43 \pm 0.07$ & 11 & $0.35 \pm 0.04$ & 10 & 0.30 \\
\hline $\mathrm{TNF} \alpha(\mathrm{pg} / \mathrm{mL})$ & $7.2 \pm 0.3$ & 11 & $8.2 \pm 0.7$ & 12 & 0.25 \\
\hline C-reactive protein $(\mathrm{ng} / \mathrm{mL})$ & $7.5 \pm 0.3$ & 8 & $7.3 \pm 0.6$ & 7 & 0.78 \\
\hline
\end{tabular}

Data are the mean \pm SE $(n) .{ }^{a}$ NEFA: Non-esterified fatty acids; ${ }^{*} P$ values according to the Student $t$ test. 

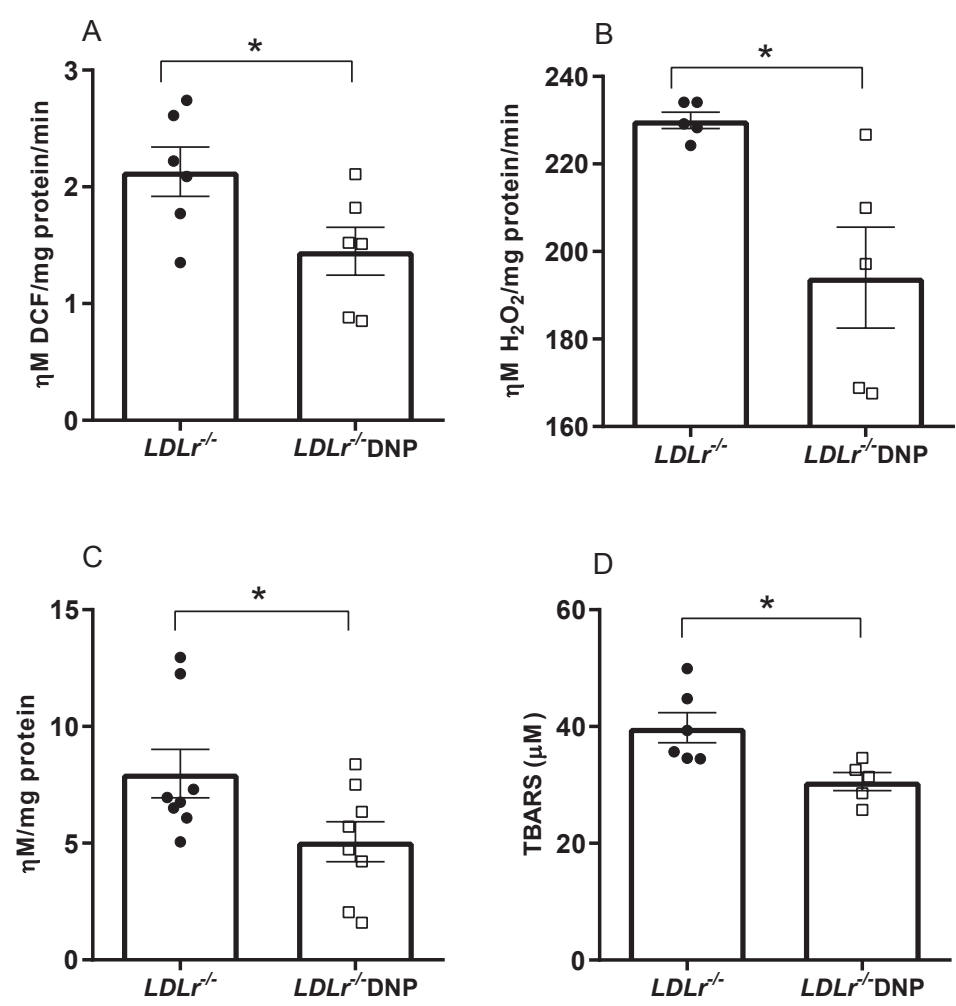

Fig. 2. Systemic and liver oxidative damage markers and oxidant production by isolated liver mitochondria in male LDL receptor knockout mice $\left(L D L r^{-1-}\right)$ treated with or without 2,4-dinitrophenol (DNP)

(A) Global oxidant production in liver mitochondria $\left(n=6,{ }^{*} p=0.044\right)$. (B) $\mathrm{H}_{2} \mathrm{O}_{2}$ release by liver mitochondria $\left(n=5,{ }^{*} p=0.02\right)$. (C) Liver protein carbonyl content $\left(n=8,{ }^{*} p=0.047\right)$. (D) Plasma thiobarbituric acid-reactive substances (TBARSs) $\left(n=5-6,{ }^{*} p=0.02\right)$.

(Supplementary Fig. 1).

Oxidant production rates were analyzed in isolated liver mitochondria. As expected, the global mitochondrial oxidant production (probed with $\mathrm{H}_{2} \mathrm{DCF}-\mathrm{DA}$ ) and the $\mathrm{H}_{2} \mathrm{O}_{2}$ release rate (probed with Amplex red and HRP) were significantly diminished by $32 \%$ and $16 \%$, respectively, in organelles obtained from DNP-treated mice (Fig. 2 A, B). In addition, liver protein carbonyl content and plasma levels of thiobarbituric acid-reactive substances (TBARS) were decreased by $36 \%$ and $23 \%$, respectively, in DNPtreated mice, indicating a decrease in tissue protein oxidation and plasma lipoperoxidation in DNPtreated mice (Fig. 2 C, D). Reduced and oxidized glutathione contents in the liver and mitochondrial density measured as citrate synthase activity were similar between the groups (Supplementary Fig. 2).

We also analyzed the effects of DNP on oxidant production by the cells (macrophages) and tissue (aorta) directly related to atherosclerosis. The data on oxidant production in peritoneal macrophages and aortic rings from DNP-treated mice are shown in Fig. 3. Macrophages from DNP-treated mice released $30 \%$ less $\mathrm{H}_{2} \mathrm{O}_{2}$ than those from the untreated mice, while markedly elevated levels of $\mathrm{H}_{2} \mathrm{O}_{2}$ were observed after stimulating the cells with the phorbol ester PMA (which activates NADPH oxidase) (Fig.3A). The aorta from the DNP-treated mice had global oxidant (DCF) and $\mathrm{H}_{2} \mathrm{O}_{2}$ decreased release by $25 \%$ and $18 \%$, respectively (Fig.3B, C). We then measured early spontaneous atherosclerosis in the aortic root in these mice fed with chow diet and observed a significant $36 \%$ decrease in the lipid-stained lesion areas of DNPtreated mice (Fig. 3D).

Since spontaneous atherosclerosis in chow fed mice showed only small lesions in the aorta root, we fed mice a western-type diet (22 $\mathrm{g} \%$ fat) containing cholesterol $(0.21 \%)$ to evaluate the effect of DNP treatment under diet induced atherosclerosis conditions. The LDL receptor knockout mice were treated simultaneously with DNP and the atherogenic diet for 4 weeks (Fig.4). Peritoneal macrophages from the DNP-treated mice fed with the atherogenic diet showed a $25 \%$ reduction in total superoxide production (DHE) (Fig. 4A) and a 35\% reduction in mitochondria-derived superoxide (Mitosox) (Fig.4B). More importantly, the aortic atherosclerotic lesion area was $26 \%$ smaller in the DNP-treated mice fed

\section{Advance Publication Journal of Atherosclerosis and Thrombosis}



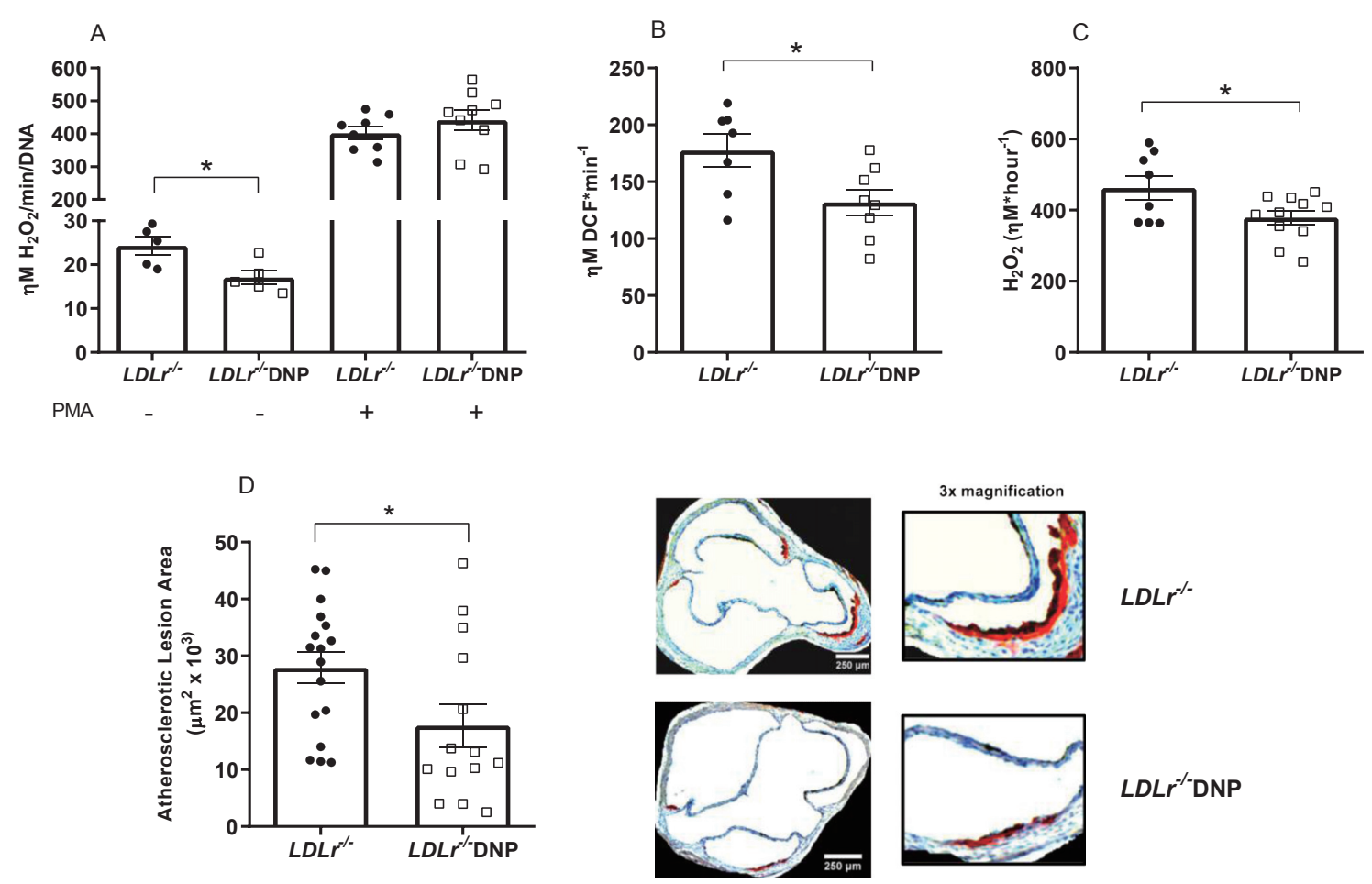

Fig. 3. Oxidant production in peritoneal macrophages and aorta and spontaneous atherosclerosis in male LDL receptor knockout mice $\left(L D L r^{-1-}\right)$ treated with or without 2,4-dinitrophenol (DNP)

(A) $\mathrm{H}_{2} \mathrm{O}_{2}$ release in peritoneal macrophages incubated with or without $100 \mathrm{nM}$ phorbol 12 -myristate 13 -acetate $(\mathrm{PMA})\left(n=5\right.$-9, $\left.{ }^{*} p=0.025\right)$. (B) Global (DCF) oxidant production in aortic rings $\left(n=7-8,{ }^{*} p=0.025\right)$. (C) $\mathrm{H}_{2} \mathrm{O}_{2}$ release in aortic rings probed with Amplex red $(n=8-11$, $\left.{ }^{*} p=0.036\right)$. (D) Lipid-stained areas of atherosclerotic lesions in the aortic root and representative images $\left(n=14-17,{ }^{*} p=0.033\right)$.

the atherogenic diet (Fig. $4 \mathrm{C})$. The macrophage content of lesions were determined using CD68 antibody (Fig.4D). Indeed, DNP treated mice presented lower content of macrophages $(-33 \%)$ in their aorta root, suggesting a less inflamed type of lesion.

Similar to the results observed under low-fat chow diet, the DNP-treated mice fed the atherogenic diet had no significant changes in the adiposity and plasma lipids levels (Supplementary Table 1).

In order to further explore the DNP effects on macrophages, we performed in vitro experiments (Fig. 5). A DNP dose-effect experiment was done to stablish the experimental conditions. The DNP dose of $100 \mu \mathrm{M}$ during 24 hour incubation significantly decreased $\mathrm{H}_{2} \mathrm{O}_{2}$ release without perturbations in cell viability (Fig. 5A and B) and, thus, this dose was chosen for further experiments. DNP in vitro treatment of peritoneal macrophages from hypercholesterolemic mice showed $40 \%$ reduced $\mathrm{H}_{2} \mathrm{O}_{2}$ production (Fig. $5 \mathrm{C}$ ) and modified the inflammatory profile (Fig.5D, E), phagocytosis activity (Fig. 5F) and lipid uptake and accumulation (Fig. 5G). Concerning inflammation related gene expression (Fig. 5D), we observe that DNP induced marked increases (3-5 fold) in the expression of antiinflammatory genes such as IL-4, IL-10 and arginase-1. On the other hand, DNP significantly decreased TNF $\alpha$ and increased IL- $1 \beta$ and IL- 6 . While TNF $\alpha$ and IL- $1 \beta$ are pro-inflammatory genes, IL- 6 is a cytokine found to be elevated in both pro- or antiinflammatory settings. This finding is related with the time frame and specific context in which the cytokine is measured, because one classical role of IL-6 is to signal and activate the expression of the antiinflammatory response ${ }^{40)}$. These results thus suggest a transition state towards a less inflammatory phenotype. DNP induced IL-10 expression was confirmed by a 3-fold elevation in IL-10 secretion into the cell media (Fig.5E). Functionally, DNP induced phagocytosis activity in treated macrophages (Fig. 5F). This is compatible with M2 (antiinflammatory) macrophage phenotype that usually exhibit high phagocytic activity ${ }^{41)}$. Finally, LDLcholesterol uptake and accumulation in macrophages, as a measure of foam cell formation, was 43\% decreased in DNP treated cells (Fig. 5G).

\section{Advance Publication Journal of Atherosclerosis and Thrombosis}



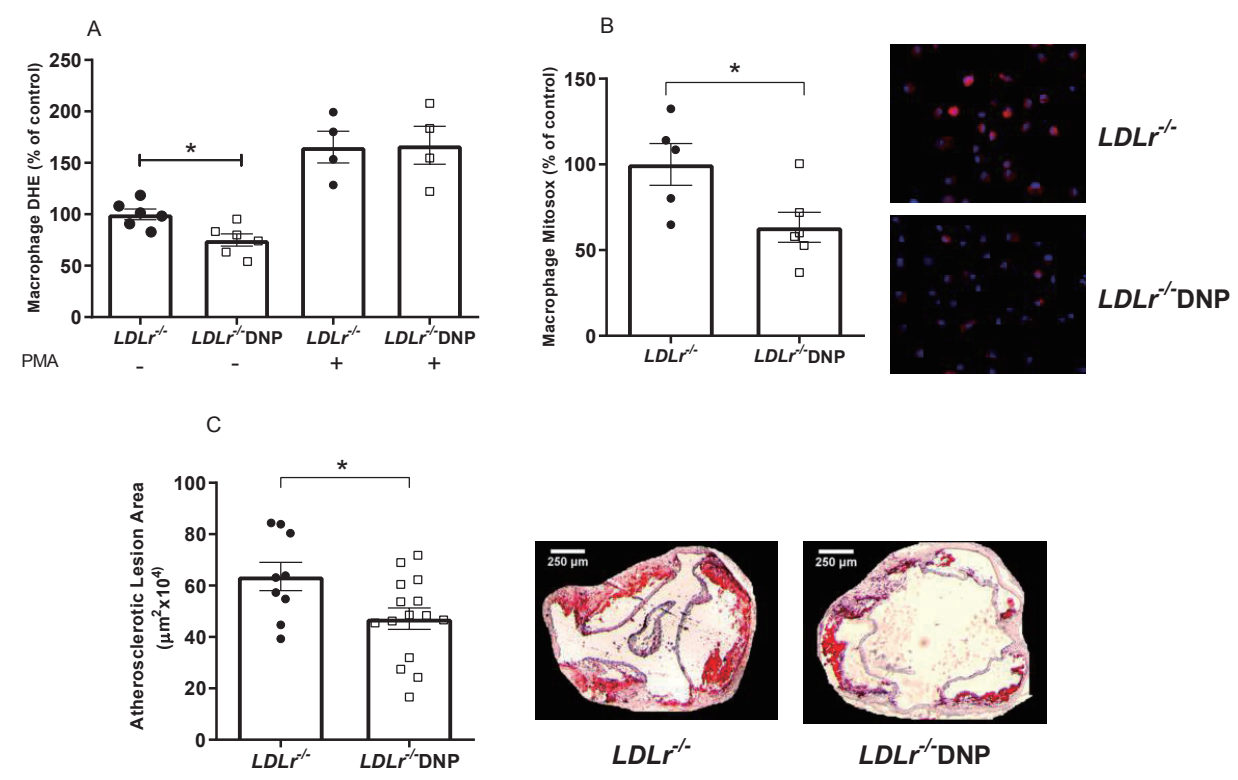

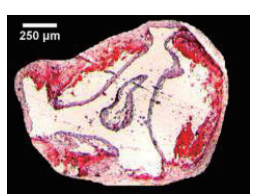

$L D L r^{-1-}$

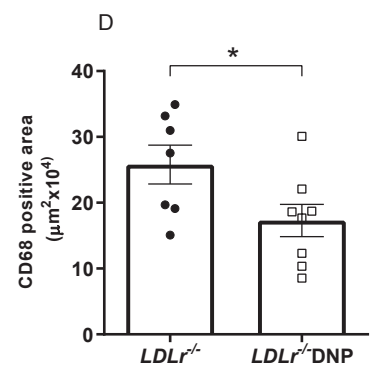

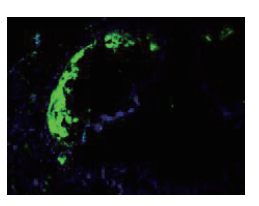

$L D L r^{-1-}$

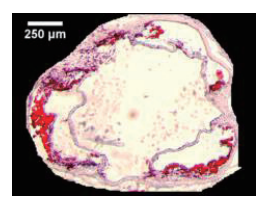

$L D L r^{-1}$ DNP

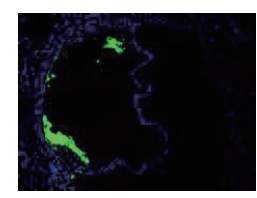

$L D L r^{-/}$-DNP

Fig.4. Peritoneal macrophage superoxide production and diet-induced atherosclerosis in LDL receptor knockout male and female mice $\left(L D L r^{-1-}\right)$ treated with 2,4-dinitrophenol (DNP) and fed with an atherogenic diet

(A) Superoxide production (DHE) in peritoneal macrophages incubated with or without $100 \mathrm{nM}$ phorbol 12-myristate 13-acetate (PMA) $\left(n=4-6,{ }^{*} p=0.01\right)$. (B) Mitochondrial superoxide production (Mitosox) and representative images of peritoneal macrophages $\left(n=5-6,{ }^{*} p=0.03\right)$. (C) Lipid-stained areas of atherosclerotic lesions in the aortic root and representative images $(n=9-15, * p=0.026)$. (D) Anti-CD68 (macrophage marker) stained areas of lesions in the aortic root and representative images $\left(n=7-8,{ }^{*} p=0.024\right)$.

\section{Discussion}

The oxidative modification hypothesis of atherosclerosis $^{42)}$ has been continuously supported since its proposal. Therefore, the efforts to counteract oxidant stress have been tested in several trials using antioxidant supplementation; however, none of the trials have successfully reduced atherosclerosis ${ }^{3)}$. In this study, we hypothesized that counteracting endogenous production of oxidants, specifically oxidants derived from mitochondria, can beneficially impact atherosclerosis development. Indeed, we showed that inducing a mild mitochondrial uncoupling and thus reducing oxidant generation results in a decrease in spontaneous and diet-induced atherosclerosis development in the hypercholesterolemic $\mathrm{LDLr}^{-1-}$ model. The treatment with low doses of DNP did not alter classical risk factors for cardiovascular diseases, such as plasma lipids, glucose homeostasis, adiposity and systemic inflammation markers in the $\mathrm{LDLr}^{-1-}$ mice, reinforcing that mitochondrial reactive oxygen species in the arterial wall have a key pro-atherogenic role.

Low dose DNP treatment also promotes other beneficial metabolic effects in other experimental models. In normolipidemic Swiss mice, a long treatment with DNP ( $>5$ months) improved plasma glucose and triglyceride levels and reduced body weight ${ }^{23)}$. Goldgof et al. showed that DNP treatment attenuated obesity in mice acclimated at thermoneutrality, but no changes were observed in body weight, adiposity and glucose homeostasis in mice maintained at the standard $22^{\circ} \mathrm{C}^{24}$. There is evidence that mitochondrial uncoupling may indeed protect against metabolic diseases. Niclosamide ethanolamine, an anthelmintic drug, uncouples mitochondria and protects against high-fat dietinduced hepatic steatosis and insulin resistance.

\section{Advance Publication Journal of Atherosclerosis and Thrombosis}



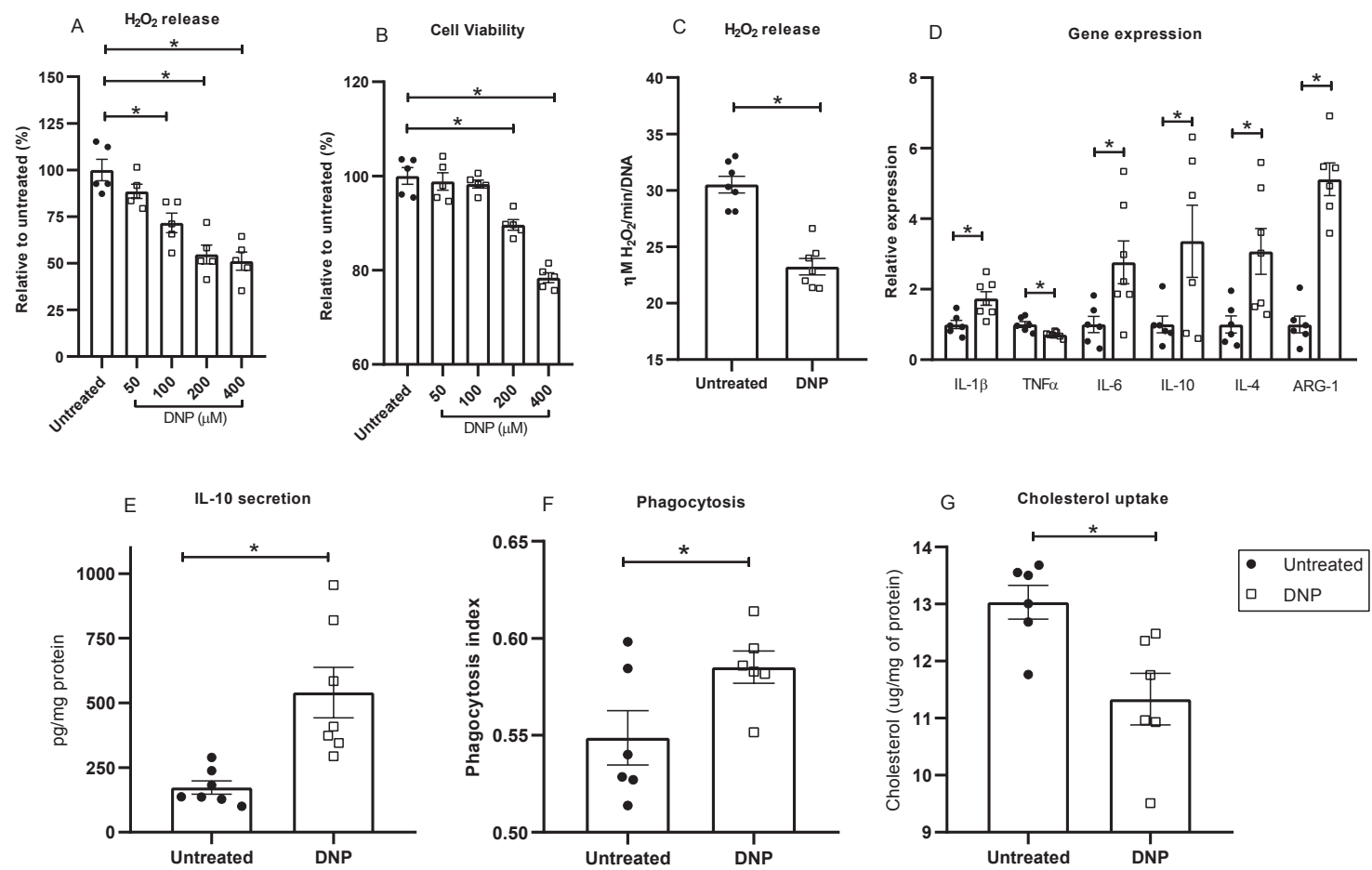

Fig. 5. In vitro effects of $\mathrm{DNP}$ on $L D L r$-/- peritoneal macrophage $\mathrm{H}_{2} \mathrm{O}_{2}$ production $(\mathrm{A}, \mathrm{C})$, cell viability (B), inflammation related gene expression (D), IL-10 secretion (E), phagocytic activity $(\mathrm{F})$ and cholesterol uptake upon incubation with oxidized LDL $(50 \mu \mathrm{g} / \mathrm{mL})(\mathrm{G})$

In all experiments cells were incubated $24 \mathrm{~h}$ at $37^{\circ} \mathrm{C}$. Panels $\mathrm{C}$ to $\mathrm{G}$ show cells treated with $100 \mu \mathrm{M}$ DNP. See Material and Methods Sections for details. IL-1 $\beta$, IL-4 and IL-10 gene expressions were normalized with ACTB (Actin Beta) while TNF-a, IL-6 and ARG1 genes were normalized with 36B4 (acidic ribosomal phosphoprotein). Experiments show mean \pm SE and individual experimental points $(n=5-7 L D L r-/-$ macrophage donor mice), ${ }^{*} p<0.05$.

Moreover, the drug improved glycemic control of $\mathrm{db} /$ $\mathrm{db}$ mice ${ }^{43}$. Yet, a controlled-release mitochondrial protonophore that produces mild liver-targeted mitochondrial uncoupling reversed diabetes and steatohepatitis in rats ${ }^{44)}$ and decreased hypertriglyceridemia and reverse nonalcoholic steatohepatitis (NASH) and diabetes in a mouse model of severe lipodystrophy and diabetes ${ }^{45)}$. Another mitochondrial uncoupler, BAM15, induced anti-obesity effects and increased insulin sensitivity in mice fed a western type diet ${ }^{46)}$. In addition, Sorafenib, a drug used to treat hepatocellular carcinoma that elicits serious side effects, when employed in a $1 / 10$ of the clinical dose, induces mild mitochondrial uncoupling and prevents the progression of NASH in mice and monkeys without adverse effects ${ }^{47}$. However, no previous studies have evaluated the association of mitochondrial uncoupling and atherosclerosis.

We have shown previously that the hypercholesterolemic LDL receptor knockout mice exhibited increased mitochondrial oxidant production in several tissues ${ }^{32,33)}$. In this study, we demonstrated that treatment with the mitochondrial uncoupler
DNP decreases the mitochondrial oxidant production and oxidative damage in various tissues (liver, plasma, macrophages and aorta) of $\mathrm{LDLr}^{-/-}$mice. Similar results in other tissues were found in Swiss mice treated in vivo with low doses of $\mathrm{DNP}^{23)}$. The authors demonstrated that DNP treatment enhanced tissue respiration rates due to mild mitochondrial uncoupling. Moreover, muscle cells treated with DNP exhibit a reduction in mitochondrial oxidant production $^{48)}$.

Attenuation of spontaneous and diet-induced development of atherosclerosis by DNP treatment, independently of classical risk factors, indicates that mitochondrial superoxide and $\mathrm{H}_{2} \mathrm{O}_{2}$ production are causally related to atherosclerosis. These findings confirm and expand our previous reports on a positive correlation between mitochondrial oxidants and severity of atherosclerosis ${ }^{9,10)}$. In line with our results, but using a genetic approach, Wang et al. improved the mitochondrial antioxidant capacity in macrophages by ectopically overexpressing catalase in mitochondria and observed reduced atherosclerotic lesion area in $\mathrm{LDLr}^{-/-}$mice ${ }^{11,12)}$. Since DNP is a 
lipophilic highly specific proton translocator, it is likely that, in vivo, DNP acts in several tissue mitochondria. As we showed, DNP reduced oxidants production in liver, macrophages and aorta. These effects probably also include smooth muscle cells and endothelial cells, which are very relevant for atherosclerosis development. Thus, in vivo treatment with DNP contributes to local (arterial) and systemic antioxidant environment, attenuating atherosclerosis development.

Mild mitochondrial uncoupling has long ago been proposed as part of a cellular defense system to prevent the formation of superoxide ${ }^{49)}$. More recently, mitochondrial uncoupling has been identified as a cytoprotective strategy under conditions of oxidative stress, including diabetes, drug-resistance in tumor cells, ischemia-reperfusion (IR) injury or aging ${ }^{50)}$ and, as proposed here, atherosclerosis. In terms of mechanisms, attenuation of mitochondrial oxidant production in the arterial wall may directly prevent the early atherogenic events, such as LDL oxidation, endothelial cell activation and recruitment of immune cells to arterial wall. In endothelial cells, oxidative stress induces the expression of several adhesion and chemotactic molecules that recruit immune cell and initiate local inflammation and atherogenesis ${ }^{51)}$. In vascular smooth muscle cells, genes involved in migration (fibronectin), proliferation (p105 coactivator) and apoptosis (ECA39) were shown to be upregulated by $\mathrm{H}_{2} \mathrm{O}_{2}{ }^{52)}$. After overexpressing mitochondrial catalase in macrophages of LDLr-/mice, Wang et al. (2014) observed attenuation of NF-kB pathway and suppression of MCP-1 and other inflammatory markers. Thus, NF-kB is a pathway likely deactivated in macrophages of DNP treated hypercholesterolemic mice, as well as JNK and p38 and downstream inflammatory cytokines expression. We showed here that DNP treated macrophages exhibit a response compatible with a transition towards a less inflammatory phenotype shown by marked increases in IL-4, IL-10 and Arg-1 gene expression, 3 fold increase in IL-10 secretion and higher phagocytic activity. More importantly, DNP treated macrophages take up less LDL-cholesterol thus decreasing foam cell formation rates.

Further redox mechanisms triggered by DNP may be raised. Vilne et al. have shown that, under hypercholesterolemia, there is a marked downregulation of mitochondrial genes in the aortic arches of the $\mathrm{Ldlr}^{-1-} \mathrm{Apob}^{100 / 100}$ mouse model ${ }^{53)}$. The authors identified the transcription factor estrogen related receptor (ERR)- $\alpha$ and its co-factors PGC1- $\alpha$ and $-\beta$ as key regulatory genes that were inversely correlated with atherosclerosis expansion. These genes are known to promote mitochondrial biogenesis and antioxidant responses. Thus, by decreasing aorta mitochondrial derived oxidants in hypercholesterolemia, mild uncoupling may counter regulate these and other key genes related with redox homeostasis and atherosclerosis. A large number of genes responsive to oxidative stress could be modulated by mild mitochondrial uncoupling. For instance, mitochondrial oxidants activate Nrf2 that induce the expression of antioxidant genes. However, in response to severe oxidative stress, $\mathrm{Nrf} 2$ induces Klf9 expression, which represses antioxidant enzymes and enhances cell death ${ }^{54)}$. Thus, eliminating excessive oxidants by mild mitochondrial uncoupling could rescue Nrf2 expression and decrease the development of the disease. The identification of more relevant genes that could be regulated by mild mitochondrial uncoupling would require an "omics" approach in each specific vascular cell type.

Altogether, these findings support the research for new drug design targeting mild mitochondrial uncoupling as an effective strategy of stimulating endogenous antioxidant mechanism. In addition, available drugs with known mild uncoupling activity, such as the anthelmintic niclosamide ethanolamine, might be tested as a potential repurposed drug for attenuating arterial oxidative stress and atherosclerosis.

\section{Conclusion}

The present findings are a proof of concept that activation of mild mitochondrial uncoupling is sufficient to delay atherosclerosis development in hypercholesterolemia. These results promote future approaches targeting mitochondria for prevention or treatment of atherosclerosis.

\section{Acknowledgements AND Notice of Grant Support}

We are grateful for the excellent technical assistance of Andressa Fagundes.

This work was supported by grants from Fundação de Amparo à Pesquisa do Estado de São Paulo to AEV and HCFO (FAPESP \#2013/07607-8, \#2017/17728-8) and Conselho Nacional de Desenvolvimento Científico e Tecnológico (CNPq \#300937/2018-0). GGD was supported by CNPq (\# 151345/2013-9) and FAPESP (\#2017/02903-9) fellowships; JCR (\#2014/02819-0), BAP (\# 2009/53762-0), LHPA (\# 2017/03402-3) were supported by FAPESP fellowships. 


\section{Conflicts of Interest}

Authors have no conflicts of interest to declare.

\section{References}

1) Moore KJ, Sheedy FJ and Fisher EA: Macrophages in atherosclerosis: a dynamic balance. Nat Rev Immunol, 2013; 13: 709-721

2) Geovanini GR and Libby P: Atherosclerosis and inflammation: overview and updates. Clin Sci, 2018; 132: $1243-1252$

3) Thomson MJ, Puntmann V and Kaski JC: Atherosclerosis and oxidant stress: the end of the road for antioxidant vitamin treatment? Cardiovasc Drugs Ther, 2007; 21: $195-210$

4) Steinhubl SR: Why have antioxidants failed in clinical trials? Am J Cardiol, 2008; 101: 14D-19D

5) Sies $\mathrm{H}$ and Jones DP: Reactive oxygen species (ROS) as pleiotropic physiological signalling agents. Nat Rev Mol Cell Biol, 2020; 7: 363-383

6) Boveris $A$ and Chance B: The mitochondrial generation of hydrogen peroxide. General properties and effect of hyperbaric oxygen. Biochem J, 1973; 134: 707-716

7) Figueira TR, Barros $M H$, Camargo AA, Castilho RF, Ferreira JC, Kowaltowski AJ, Sluse FE, Souza-Pinto NC, Vercesi AE: Mitochondria as a source of reactive oxygen and nitrogen species: from molecular mechanisms to human health. Antioxid Redox Signal, 2013; 18: 20292074

8) Kowaltowski AJ, de Souza-Pinto NC, Castilho RF, Vercesi AE: Mitochondria and reactive oxygen species. Free Radic Biol Med, 2009; 47: 333-343

9) Dorighello GG, Paim BA, Kiihl SF, Ferreira MS, Catharino RR, Vercesi AE, Oliveira HC: Correlation between Mitochondrial Reactive Oxygen and Severity of Atherosclerosis. Oxid Med Cell Longev, 2016; 2016: 7843685

10) Dorighello GG, Paim BA, Leite ACR, Vercesi AE, Oliveira HCF: Spontaneous experimental atherosclerosis in hypercholesterolemic mice advances with ageing and correlates with mitochondrial reactive oxygen species. Exp Gerontol, 2018; 109: 47-50

11) Wang Y, Wang GZ, Rabinovitch PS, Tabas I: Macrophage mitochondrial oxidative stress promotes atherosclerosis and nuclear factor-kappaB-mediated inflammation in macrophages. Circ Res, 2014; 114: 421-433

12) Wang Y, Wang W, Wang N, Tall AR, Tabas I: Mitochondrial Oxidative Stress Promotes Atherosclerosis and Neutrophil Extracellular Traps in Aged Mice. Arterioscler Thromb Vasc Biol, 2017; 37: e99-e107

13) Yu EPK, Reinhold J, Yu H, Starks L, Uryga AK, Foote K, Finigan A, Figg N, Pung YF, Logan A, Murphy MP, Bennett M: Mitochondrial Respiration Is Reduced in Atherosclerosis, Promoting Necrotic Core Formation and Reducing Relative Fibrous Cap Thickness. Arterioscler Thromb Vasc Biol, 2017; 37: 2322-2332

14) Oliveira HCF and Vercesi AE: Mitochondrial bioenergetics and redox dysfunctions in hypercholesterolemia and atherosclerosis. Mol Aspects Med, 2020; 71: 100840
15) Oyewole AO and Birch-Machin MA: Mitochondriatargeted antioxidants. FASEB J, 2015; 29: 4766-4771

16) Smith RA, Hartley RC and Murphy MP: Mitochondriatargeted small molecule therapeutics and probes. Antioxid Redox Signal, 2011; 15: 3021-3038

17) Mercer JR, Yu E, Figg N, Cheng KK, Prime TA, Griffin JL, Masoodi M, Vidal-Puig A, Murphy MP, Bennett MR: The mitochondria-targeted antioxidant MitoQ decreases features of the metabolic syndrome in ATM+/-/ApoE-/mice. Free Radic Biol Med, 2012; 52: 841-849

18) Vendrov AE, Vendrov KC, Smith A, Yuan J, Sumida A, Robidoux J, Runge MS, Madamanchi NR: NOX4 NADPH Oxidase-Dependent Mitochondrial Oxidative Stress in Aging-Associated Cardiovascular Disease. Antioxid Redox Signal, 2015; 23: 1389-1409

19) Vozenilek AE, Vetkoetter M, Green JM, Shen X, Traylor JG, Klein RL, Orr AW, Woolard MD, Krzywanski DM: Absence of Nicotinamide Nucleotide Transhydrogenase in C57BL/6J Mice Exacerbates Experimental Atherosclerosis. J Vasc Res, 2018; 55: 98-110

20) Bonora M, Wieckowski MR, Sinclair DA, Kroemer G, Pinton P, Galluzzi L: Targeting mitochondria for cardiovascular disorders: therapeutic potential and obstacles. Nat Rev Cardiol, 2019; 16: 33-55

21) Tainter ML, Stockton $A B$ and Cutting WC: Dinitrophenol in the treatment of obesity - Final report. JAMA, 1935; 105: 0332-0337

22) Grundlingh J, Dargan PI, El-Zanfaly M, Wood DM: 2,4-dinitrophenol (DNP): a weight loss agent with significant acute toxicity and risk of death. J Med Toxicol, 2011; 7: 205-212

23) Caldeira da Silva CC, Cerqueira FM, Barbosa LF, Medeiros MH, Kowaltowski AJ: Mild mitochondrial uncoupling in mice affects energy metabolism redox balance and longevity. Aging Cell, 2008; 7: 552-560

24) Goldgof M, Xiao C, Chanturiya T, Jou W, Gavrilova O, Reitman ML: The chemical uncoupler 2,4-dinitrophenol (DNP) protects against diet-induced obesity and improves energy homeostasis in mice at thermoneutrality. J Biol Chem, 2014; 289: 19341-19350

25) Kishimoto Y, Johnson J, Fang W, Halpern J, Marosi K, Liu D, Geisler JG, Mattson MP: A mitochondrial uncoupler prodrug protects dopaminergic neurons and improves functional outcome in a mouse model of Parkinson's disease. Neurobiol Aging, 2020; 85: 123-130

26) Jiao S, Cole TG, Kitchens RT, Pfleger B, Schonfeld G: Genetic heterogeneity of lipoproteins in inbred strains of mice: analysis by gel-permeation chromatography. Metabolism, 1990; 39: 155-160

27) Salerno AG, Silva TR, Amaral ME, Alberici LC, Bonfleur ML, Patrício PR, Francesconi EP, Grassi-Kassisse DM, Vercesi AE, Boschero AC, Oliveira HC: Overexpression of apolipoprotein CIII increases and CETP reverses dietinduced obesity in transgenic mice. Int J Obes, 2007; 31: 1586-1595

28) Folch J, Lees M and Sloane Stanley GH: A simple method for the isolation and purification of total lipides from animal tissues. J Biol Chem, 1957; 226: 497-509

29) Reznick AZ and Packer L: Oxidative damage to proteins: spectrophotometric method for carbonyl assay. Methods Enzymol, 1994; 233: 357-363 
30) Schild L, Reinheckel T, Wiswedel I, Augustin W: Shortterm impairment of energy production in isolated rat liver mitochondria by hypoxia/reoxygenation: involvement of oxidative protein modification. Biochem J, 1997; 328: 205-210

31) Kaplan RS and Pedersen PL: Characterization of phosphate efflux pathways in rat liver mitochondria. Biochem J, 1983; 212: 279-288

32) Oliveira HC, Cosso RG, Alberici LC, Maciel EN, Salerno AG, Dorighello GG, Velho JA, de Faria EC, Vercesi AE: Oxidative stress in atherosclerosis-prone mouse is due to low antioxidant capacity of mitochondria. FASEB J, 2005; 19: 278-280

33) Paim BA, Velho JA, Castilho RF, Oliveira HC, Vercesi AE: Oxidative stress in hypercholesterolemic LDL (lowdensity lipoprotein) receptor knockout mice is associated with low content of mitochondrial NADP-linked substrates and is partially reversed by citrate replacement. Free Radic Biol Med, 2008; 44: 444-451

34) Dikalov S, Griendling KK and Harrison DG: Measurement of reactive oxygen species in cardiovascular studies. Hypertension, 2007; 49: 717-727

35) Livak KJ, Schmittgen TD: Analysis of relative gene expression data using real-time quantitative PCR and the 2(-Delta Delta C(T)) Method. Methods, 2001; 25(4): 402-408

36) de Lima C, Alves LE, Iagher F, Machado AF, Bonatto SJ, Kuczera D, de Souza CF, Pequito DC, Muritiba AL, Nunes EA, Fernandes, LC: Anaerobic exercise reduces tumor growth, cancer cachexia and increases macrophage and lymphocyte response in Walker 256 tumor-bearing rats. Eur J Applied Physiol, 2008; 104: 957-964

37) Robinet, P., Wang, Z., Hazen, S.L., and Smith, J.D: A simple and sensitive enzymatic method for cholesterol quantification in macrophages and foam cells. J Lipid Res, 2010; 51: 3364-3369

38) Hayashi T, Hirshman MF, Fujii N, Habinowski SA, Witters LA, Goodyear LJ: Metabolic stress and altered glucose transport: activation of AMP-activated protein kinase as a unifying coupling mechanism. Diabetes, 2000; 49: 527-531

39) Hardie DG: AMPK: a key regulator of energy balance in the single cell and the whole organism. Int J Obes, 2008; 32 Suppl 4: S7-12

40) Scheller J, Chalaris A, Schmidt-Arras D, Rose-John S: The pro- and anti-inflammatory properties of the cytokine interleukin-6. Biochim Biophys Acta, 2011; 1813: 878-888

41) Yunna C, Mengru H, Lei W, Weidong C: Macrophage M1/M2 polarization. Eur J Pharmacol, 2020; 877: 173090

42) Chisolm GM, Steinberg D: The oxidative modification hypothesis of atherogenesis: an overview. Free Radic Biol Med, 2000; 28: 1815-1826
43) Tao H, Zhang Y, Zeng X, Shulman GI, Jin S: Niclosamide ethanolamine-induced mild mitochondrial uncoupling improves diabetic symptoms in mice. Nat Med, 2014; 20: 1263-1269

44) Perry RJ, Zhang D, Zhang XM, Boyer JL, Shulman GI: Controlled-release mitochondrial protonophore reverses diabetes and steatohepatitis in rats. Science, 2015; 347: 1253-1256

45) Abulizi A, Perry RJ, Camporez JPG, Jurczak MJ, Petersen KF, Aspichueta P, Shulman GI: A controlled-release mitochondrial protonophore reverses hypertriglyceridemia, nonalcoholic steatohepatitis, and diabetes in lipodystrophic mice. FASEB J, 2017; 31: 2916-2924

46) Alexopoulos SJ, Chen SY, Brandon AE, Salamoun JM, Byrne FL, Garcia CJ, Beretta M, Olzomer EM, Shah DP, Philp AM, Hargett SR, Lawrence RT, Lee B, Sligar J, Carrive P, Tucker SP, Philp A, Lackner C, Turner N, Cooney GJ, Santos WL, Hoehn KL: Mitochondrial uncoupler BAM15 reverses diet-induced obesity and insulin resistance in mice. Nat Commun, 2020; 11: 2397

47) Jian C, Fu J, Cheng X, Shen LJ, Ji YX, Wang X, Pan S, Tian H, Tian S, Liao R, Song K, Wang HP, Zhang X, Wang Y, Huang Z, She ZG, Zhang XJ, Zhu L, Li H: Low-Dose Sorafenib Acts as a Mitochondrial Uncoupler and Ameliorates Nonalcoholic Steatohepatitis. Cell Metab, 2020; 31(5): 892-908

48) MacLellan JD, Gerrits MF, Gowing A, Smith PJ, Wheeler $\mathrm{MB}$, Harper ME: Physiological increases in uncoupling protein 3 augment fatty acid oxidation and decrease reactive oxygen species production without uncoupling respiration in muscle cells. Diabetes, 2005; 54: 23432350

49) Skulachev VP: Uncoupling: new approaches to an old problem of bioenergetics. Biochim Biophys Acta, 1998; 1363: 100-124

50) Cadenas S: Mitochondrial uncoupling, ROS generation and cardioprotection. Biochim Biophys Acta Bioenerg, 2018; 1859: 940-950

51) Stocker R, Keaney JF Jr: Role of oxidative modifications in atherosclerosis. Physiol Rev, 2004; 84: 1381-1478

52) Sakamoto K, Yamasaki Y, Kaneto H, Fujitani Y, Matsuoka T, Yoshioka R, Tagawa T, Matsuhisa M, Kajimoto Y, Hori M: Identification of oxidative stress-regulated genes in rat aortic smooth muscle cells by suppression subtractive hybridization. FEBS Lett, 1999; 461: 47-51

53) Vilne B, Skogsberg J, Foroughi Asl H, Talukdar HA, Kessler T, Björkegren JLM, Schunkert H: Network analysis reveals a causal role of mitochondrial gene activity in atherosclerotic lesion formation. Atherosclerosis, 2017; 267: 39-48

54) Kasai S, Shimizu S, Tatara Y, Mimura J, Itoh K: Regulation of Nrf2 by Mitochondrial Reactive Oxygen Species in Physiology and Pathology. Biomolecules, 2020; 10: 320 


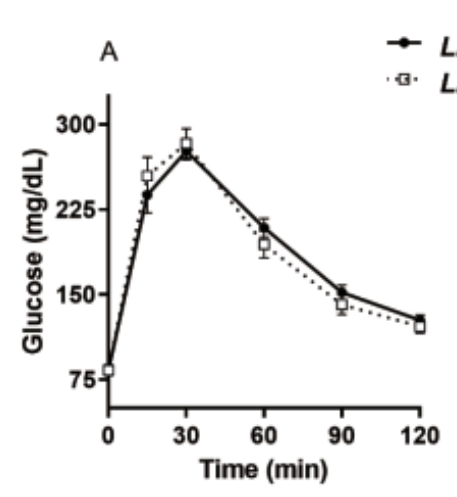

A
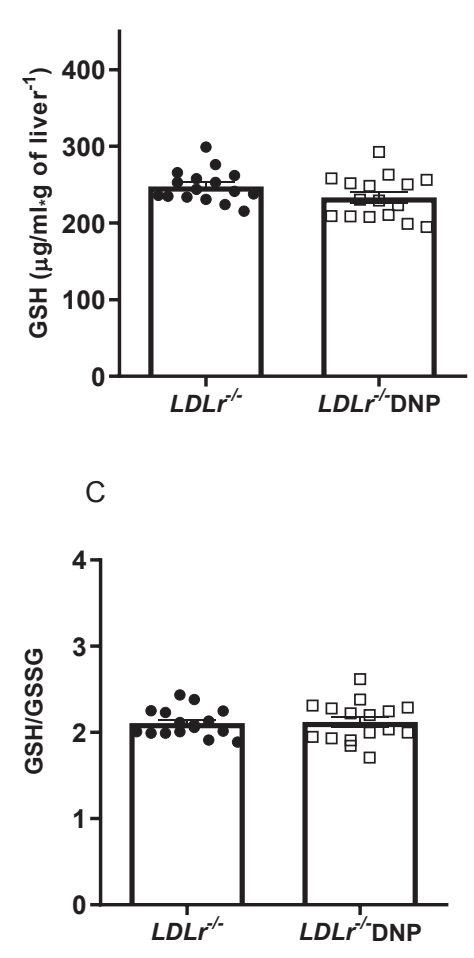

B

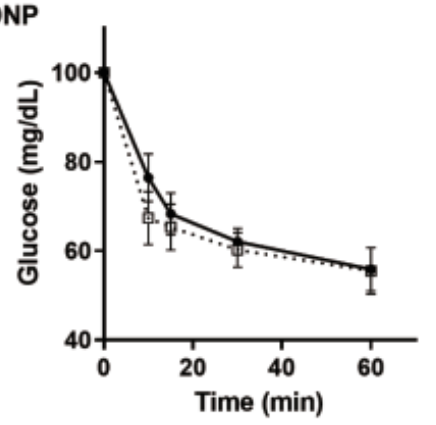

B
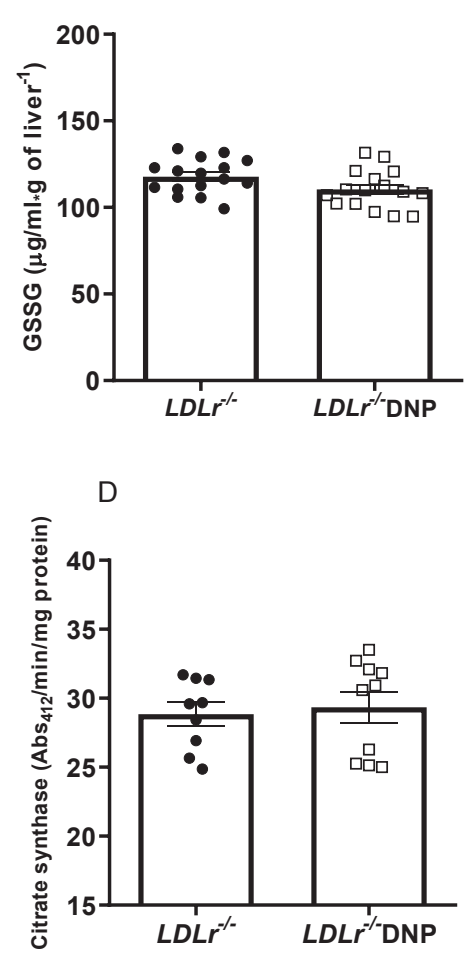

Supplementary Fig. 1. Glucose and insulin tolerance tests in LDL receptor knockout mice $\left(\mathrm{LDLr}^{-1-}\right)$ treated with or without 2,4-dinitrophenol (DNP)

(A) Glycemia curve after an oral dose of glucose $(1.5 \mathrm{~g} / \mathrm{kg}$ body weight). (B) Glycemia curve after an ip insulin injection $(0.5 \mathrm{U} / \mathrm{Kg}$ body weight $)(n=9)$.

Supplementary Fig. 2. Hepatic levels of reduced and oxidized glutathione and citrate synthase activity of $\mathrm{LDL}$ receptor knockout mice $\left(L D L r^{-1-}\right)$ treated with or without 2,4-dinitrophenol (DNP)

(A) Hepatic reduced glutathione (GSH). (B) Hepatic oxidized glutathione (GSSG). (C) GSH/GSSG ratio $(n=16)$. (D) Liver citrate synthase activity $(n=9-10)$. Reduced (GSH) and oxidized (GSSG) glutathione levels were determined in liver homogenates as described by Teare et al (1993). Citrate synthase activity was determined by the conversion of oxaloacetate and acetyl-CoA to citrate and $\mathrm{SH}-\mathrm{CoA}$ and monitored by the appearance of the thionitrobenzoic acid product at $412 \mathrm{~nm}$.

Teare, JP, Punchard, NA, Powell, JJ, et al., Automated spectrophotometric method for determining oxidized and reduced glutathione in liver, Clinical chemistry, 1993; 39: 686-689.

Supplementary Table 1. Adipose tissue mass and plasma lipid levels in LDL receptor knockout mice $\left(L D L r^{-/-}\right)$ treated with or without 2,4-dinitrophenol (DNP) and fed an atherogenic diet for 4 weeks

\begin{tabular}{lcc}
\hline & $L D L r^{-{ }^{-}}$ & $L D L r^{-1-} \mathrm{DNP}$ \\
\hline Perigonadal adipose tissue (\% body weight) & $1.51 \pm 0.13$ & $1.26 \pm 0.08$ \\
Cholesterol (mg/dL) & $520 \pm 24$ & $506 \pm 34$ \\
Triglycerides (mg/dL) & $156 \pm 9.8$ & $149 \pm 14.8$ \\
NEFA (mmol/L) & $0.46 \pm 0.03$ & $0.43 \pm 0.04$ \\
\hline
\end{tabular}

NEFA: Non-esterified fatty acids; data are the mean \pm SE $(n=9-15)$. 